\title{
OBSERVATIONS OF THE SKIN REACTION CAUSED BY A CYTOTOXIC IMMUNE SERUM IN COMPARISON WITH TUBERCULIN TEST IN GUINEA PIGS
}

\author{
KoOMI KANAI AND KEN YANAGISAWA \\ Department of Tuberculosis, National Institute of Health, Tokyo \\ (Received: February 18th, 1955)
}

\section{INTRODUCTION}

Since the discovery of Koch's phenomenon and tuberculin by Koch') and the introduction of a concept of allergy by Pirquet ${ }^{2}$, tuberculin skin test has been conducted as an indispensable tool for the diagnosis of tuberculous infection. The nature of this reaction, however, is not yet sufficiently explained, and we understand it only as a type of skin reaction in which antigen-antibody reaction may take a part in some unknown way.

On the other hand, tuberculin allergy is considered as the most representative example of the hypersensitivity called "bacterial or infectious hypersensitivity" which is resulted from the interaction between host cells and parasites. Therefore, host-parasite relationship may be different between the animals in which tuberculin allergy does not develop such as mice, rats and hamster, and those in which it develops such as guinea pigs and human beings. In this connection, it will be difficult without a proper understanding of tuberculin allergy to discuss the pathogenesis of tuberculosis.

Recently, two types of experiments have been reported which are very suggestive for the speculation of the mechanism of tuberculin reaction; one is the investigation of tuberculin-cytolysis by $\operatorname{Rich}^{3)}$, Favour ${ }^{4)}$ and so on 5) 6) 7) 8), and another is that of passive cellular transfer of tuberculin hypersensitivity by Chase ${ }^{9)}$, Kirchheimer ${ }^{10)}$, Stavitsky11), Nishioka ${ }^{12)}$, Wesslén ${ }^{13)}$ and Fukase ${ }^{14)}$. These reports may suggest that tuberculin reaction occurs on the basis of specific lysis of sensitized cells by tuberculin. Favour presented a provocative speculation on this problem as cited later. Much earlier than this, Lewis ${ }^{15)}$ had expressed an opinion that inflammatory manifestation in the skin such as redness and induration may be caused by the chemical irritation due to some substances released from destroyed cells. Quite recently, Takeda ${ }^{16)}$ attempted a series of experiments to analyze the relationship between allergy and immunity using a cytotoxic immune serum, and he explained that both are the different manifestations of the same biological process and allergy is the case when host cells are injured as the result of antigen-antibody reaction on the surface of those cells. In our preceding paper, tuberculous infection in guinea pigs 
treated with a cytotoxic immune serum was reported and the significance of allergic reaction in tuberculous infection was discussed. In the present paper, we are going to report some observations of a skin reaction caused by the cytotoxic immune serum in guinea pigs. The experiments were made on the assumption that a tuberculin-like reaction may be produced in the guinea pig skin when treated with a cytotoxic immune serum against the cells of mononuclear variety which were used in the passive transfer experiments of tuberculin hypersensitivity by Chase and so on. And on the ground of the comparative observation of it with tuberculin reaction, the mechanism of the latter was speculated.

\section{METHODS AND MATERIALS}

1) Experimental animals: Healthy rabbits weighing $2500 \mathrm{~g}$ to $3000 \mathrm{~g}$ and guinea pigs of various body weight were used.

2) Preparation of a rabbit cytotoxic immune serum against mononuclear cells of guinea pigs: Described in detail in the preceding paper.

3) Preparation of a rabbit immune serum against red cells or normal serum of guinea pigs: Described in experimental parts.

\section{EXPERIMENTAL}

1) Comparative observation of the reverse-allergic skin reaction and tuberculin reaction: Using the cytotoxic immune serum (in short CIS) of agglutinine titer $1: 800$, the skin reactions were produced in normal and tuberculous guinea pigs regarding normal rabbit serum and OT as the control materials. The animals were injected intracutaneously in the abdominal wall, one side with $0.1 \mathrm{ml}$ of CIS and another side with $0.1 \mathrm{ml}$ of one of the control materials. The reactions were read in 48 hours. The diameters of the induration were recorded in $\mathrm{mm}$ and their appearance were observed macroscopically. The results were summarized in Table 1 and 2 . It is learned from these tables that the reaction by CIS does not require the previous sensitization of guinea pigs to tuberculin. The reaction began to appear with marked erythema and oedema as early as in a few hours and then increased in the intensity of induration. In the case of severe reaction, the central part came to necrosis and circumscribed with haemorrhagic region. When the reaction was weak, it was manifested only with moderate redness and induration presenting a very similar appearance to tuberculin reaction. Oedema and redness disappeared in a relatively short period of time, but induration continued to exist for several days showing clear boundary. As described above, the skin reaction by CIS resembled to tuberculin reaction in the point of marked induration, but its early appearance with oedema was the expression characteristic to Arthus reaction rather than to the tuberculin or delayed type. The skin reaction by CIS will be considered as the reverse Arthus reaction in 
Table 1. Comparative observations of skin reactions caused by a cytotoxic immune serum and tuberculin

\begin{tabular}{|c|c|c|c|}
\hline \multirow[b]{2}{*}{$\begin{array}{l}\text { Body weight of } \\
\text { animal }\end{array}$} & \multirow[b]{2}{*}{$\begin{array}{l}\text { Animal } \\
\text { No. }\end{array}$} & \multicolumn{2}{|c|}{ Size of induration in $\mathrm{mm}$} \\
\hline & & $\begin{array}{c}\text { Right } \\
\text { Normal rabbit serum }\end{array}$ & $\begin{array}{c}\text { Left } \\
\text { Cytotoxic serum }\end{array}$ \\
\hline \multirow{3}{*}{$\begin{array}{l}\text { Normal animals } \\
330 \text { to } 380 \mathrm{~g}\end{array}$} & $\begin{array}{l}671 \\
672 \\
673\end{array}$ & $\begin{array}{l}0 \\
0 \\
0\end{array}$ & $\begin{array}{lc}17 \times 17 & (6 \times 6) \\
23 \times 23 & (10 \times 10) \\
13 \times 13 \quad(6 \times 8)\end{array}$ \\
\hline & & Cytotoxic serum & OT $(1: 10)$ \\
\hline & $\begin{array}{l}674 \\
675 \\
676\end{array}$ & $\begin{array}{ll}23 \times 23 & (10 \times 11) \\
16 \times 15 & (5 \times 6) \\
15 \times 18 & (7 \times 8)\end{array}$ & $\begin{array}{l}0 \\
0 \\
0\end{array}$ \\
\hline \multirow{4}{*}{$\begin{array}{l}\text { Tuberculous animals } \\
510 \text { to } 560 \mathrm{~g}\end{array}$} & \multirow{4}{*}{$\begin{array}{r}9 \\
17 \\
24\end{array}$} & OT $(1: 100)$ & Cytotoxic serum \\
\hline & & $\begin{array}{ll}22 \times 16 & (7 \times 7) \\
21 \times 18 & \\
13 \times 13 & \end{array}$ & $\begin{array}{ll}20 \times 20 & (6 \times 6) \\
15 \times 16 & (6 \times 6) \\
14 \times 14 & (5 \times 5)\end{array}$ \\
\hline & & Normal rabbit serum & Cytotoxic serum \\
\hline & & $\begin{array}{l}0 \\
0 \\
0\end{array}$ & $\begin{array}{l}16 \times 15 \\
13 \times 15 \\
17 \times 17\end{array}$ \\
\hline
\end{tabular}

( ) means size of central necrosis in $\mathrm{mm}$

Table 2. Comparative observations of the appearance of skin reactions caused by a cytotoxic immune serum and tuberculin

\begin{tabular}{|c|c|c|}
\hline & \multicolumn{2}{|c|}{ Appearance } \\
\hline & Tuberculin reaction & Reverse allergic reaction \\
\hline Occurrence & delayed & immediate \\
\hline Redness & marked & marked \\
\hline Induration & marked & marked \\
\hline Oedema & $\begin{array}{l}\text { accompanied only by } \\
\text { intense reaction }\end{array}$ & $\begin{array}{l}\text { always marked in the } \\
\text { early stage }\end{array}$ \\
\hline Boundary & distinct & rather diffuse \\
\hline $\begin{array}{l}\text { Hemorrhage and central } \\
\text { necrosis }\end{array}$ & $\begin{array}{l}\text { accompanied only by } \\
\text { intense reaction }\end{array}$ & easily produced \\
\hline Relation to tuberculosis & present & none \\
\hline
\end{tabular}


its form. On the other hand, it has been well known that Arthus reaction is very difficult to produce in guinea pigs. So, it is of particular interest that its reverse type was easily caused as above. Amano17) and others stated that Arthus reaction is caused by the injury of blood vessels and tuberculin reaction develops from the primary injury of the cells in the epitheliar layer of the skin. In this connection, the authors speculated that when CIS was used in the dose appropriate for giving effects only to the skin cells without penetrating into capillary vessels of the subcutaneous tissue, the skin reaction resulted presented an appearance resembling to tuberculin reaction.

2) Comparative observation of the potency of rabbit immune sera against mononuclear cells or red cells of guinea pigs in the skin or agglutination test: The cytotoxic serum was prepared as already described, and the hemagglutinine serum was prepared as follows. A 5\% saline suspension of washed guinea pig red cells was injected intravenously into rabbits twice a week, each time in the amount of $10 \mathrm{ml}$. Ten days after the final immunization, the blood was recovered from the animal. Of these two antisera the aggultinine titer was measured in vitro and at the same time each of them was injected intracutaneously to normal guinea pigs to test the potency to cause skin reaction. The agglutinine test was performed in Wasserman type tubes mixing serial dilutions of the antisera with the corresponding antigen suspensions. The reaction was read after three hours' incubation at $37^{\circ} \mathrm{C}$. As shown in Table 3, it was learned that although the anti-red cell serum was much higher in the agglutinine titer, it did not cause appreciable skin reaction in 24 hours. This fact appears to present interesting suggestions for the mechanism of tuberculin reaction.

Table 3. The agglutinine titer of antisera and their capacity to cause skin reaction

\begin{tabular}{|c|c|c|c|c|c|c|c|c|c|}
\hline & Antiserum & $1: 100$ & $1: 200$ & $1: 400$ & $\begin{array}{l}\text { Serum } \\
1: 800\end{array}$ & $\begin{array}{l}\text { dilutior } \\
1: 1600\end{array}$ & $1: 3200$ & $1: 6400$ & contr. \\
\hline \multirow{2}{*}{$\begin{array}{l}\text { Agglu- } \\
\text { tination }\end{array}$} & $\begin{array}{l}\text { cytotoxic } \\
\text { serum }\end{array}$ & H & $H$ & H & + & \pm & - & - & - \\
\hline & $\underset{\substack{\text { hemagglutinine } \\
\text { serum }}}{\text { hes }}$ & 曲 & 冊t & 册 & 册 & H & $H$ & + & - \\
\hline & & origi. & $1: 2$ & $1: 10$ & $1: 100$ & $1: 1000$ & contr. & & \\
\hline \multirow{3}{*}{$\begin{array}{l}\text { Skin } \\
\text { reaction }\end{array}$} & $\begin{array}{c}\text { cytotoxic } \\
\text { serum }\end{array}$ & H & W & $H$ & + & - & - & & \\
\hline & $\underset{\text { serum }}{\text { hemagglutinine }}$ & \pm & - & - & - & - & - & & \\
\hline & normal serum & - & - & - & - & - & - & & \\
\hline
\end{tabular}


3) Observation of the development of skin reactions caused in guinea pigs by various kinds of rabbit antisera in comparison with tuberculin reaction: In the preceding experiment, the rabbit immune serum against red cells of guinea pigs was demonstrated to be weak in the capacity to cause skin reaction in guinea pigs. The reading of the reactions, however, was made only in 24 hours. So, this time, the reactions were observed following their development since the earlier period. The materials presented to the tests were the same as those in the preceding experiment, but in addition to them the rabbit immune serum against guinea pigs normal serum was likewise used which had been prepared by the intravenous injection of the serum twice a week for three weeks, each time using $2 \mathrm{ml}$. The tests were conducted in six tuberculous guinea pigs weighing 580 to $650 \mathrm{~g}$. As experimental controls, OT and normal rabbit serum were employed. In each guinea pig, two different materials were injected intracutaneously in both sides of under abdominal wall, applying one material in one side. The reactions were recorded measuring in $\mathrm{mm}$ the size of induration or oedema in 3.5, 7, 24 and 48 hours. When central necrosis was present, its diameter was added to the size of induration for the expression of the intensity of the reaction. The results were summarized in Fig. 1. The skin réactions occurred following the intracutaneous injection of the anti-red cell serum or the anti-serum serum were constantly oedema accompanying no redness in 3.5 and 7 hours, but these manifestations disappeared almost completely in 24 hours. In other words, the reactions were temporary oedama which had no redness and did not develop into induration. The authors should like to think that these reactions were essentially an unspecific reaction, although they were intensified to some extent by the Arthus type reaction. Contrary to this, the reactions due to CIS showed a marked induration even in 48 hours after showing the maximum intensity in 7 hours. This was considered to be due to the disappearance of early oedema which was present circumscribing induration. The appearance of the reactions was as described previously. On the other hand, tuberculin reaction reached the maximum intensity in 24 hours as the delayed type of skin reaction, and presented the characteristic redness and induration. Judging from these tests, it will be easily supposed that there is little antigens in the skin which can react with the anti-red cell serum or anti-serum serum but there are much substances which are similar or the same in the antigeneity as the cells of mononuclear variety. Although there were much similarities between tuberculin reaction and the skin reaction caused by CIS, these two reactions appeared to be quite different in the rapidity of their occurrence, that is to say, the delayed type or immediate type. The reason why the reaction due to CIS occurred immediately after the injection of it will be easily understood by the probable fact that the antiserum was to be placed directly to the site where the corresponding antigens were present. On the other hand, however, the reason why tuberculin reaction occurs in the delayed type will be 


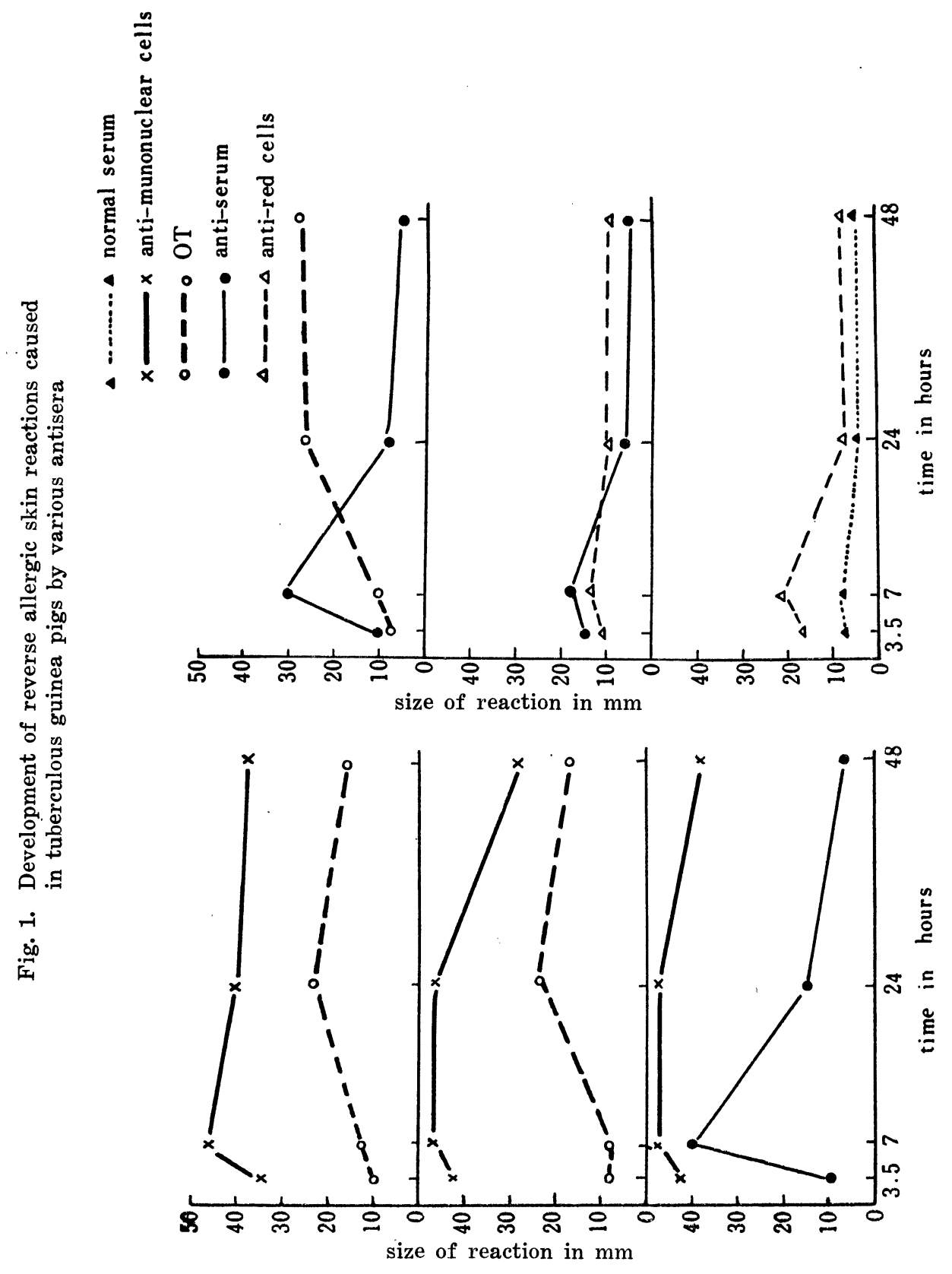


rather difficult to be explained in the present state of information. But, the speculation of it by Favour ${ }^{18)}$ is of particular interest, of which some discussions will be made later. As already stated, Arthus reaction is usually very difficult to produce in guinea pigs, particularly we encounter very rarely with intense reactions with necrosis or bleeding. This fact can be understood as follows; the intensity of Arthus reaction is parallel to the amount of circulating antibodies, but in guinea pigs the titer of circulating antibodies does not increase to high level. The reaction due to CIS may be called the reverse Arthus type reaction, but it occurred intensely in those animals. As stated above, this is no wonder, because the antiserum of high potency prepared in the body of rabbits was employed. Then, we must pay attentions to the fact that tuberculin reaction can be manifested markedly in guinea pigs nonsensitive to Arthus reaction. Almost all investigators explained that a kind of sessile antibody which is considered to be firmly attached to host cells may be associated with tuberculin reaction. Although Chase ${ }^{9), 19)}$ and others ${ }^{10), 11), 13)}$ succeeded in the passive cellular transfer of tuberculin hypersensitivity, the transferred allergy lasted only several days with weak intensity. And it will be not possible that sessile antibody is present homogeneously in every part of the skin. These points make it more difficult to explain the occurrence mechanism of tuberculin reaction. Favour ${ }^{18)}$ explained, however, quite rationally of them, although with some speculation. If tuberculin reaction is a cytolysis phenomenon in its final stage of the process, so it will be no wonder that tuberculin reaction and the skin reaction due to CIS have a common feature of their appearance. But, in the process till to the cytolysis, these two reactions may be different each other as manifested in the delayed or immediate type of occurrence.

4) Comparative observations of the Arthus type reactions in guinea pigs and rabbits: This experiment was made to confirm the fact hitherto approved that Arthus reaction is easily manifested in rabbits but not in guinea pigs. The observation was made as follows.

Exp. $\begin{gathered}\text { Immunized } \\ \text { animals }\end{gathered}$
$\begin{gathered}\text { Antigen for immunization } \\ \text { mononuclear cells of gui- } \\ \text { nea pigs }\end{gathered}$
2. rabbits $\quad$ normal guinea pig serum
3. rabbits
guinea pigs

Site of skin reaction, and its type

guinea pigs with rabbit immune serum (reverse Arthus type) rabbits with guinea pig mononuclear cells (Arthus type)

guinea pigs with rabbit immune serum (reverse Arthus type)

rabbits with guinea pig normal serum (Arthus type)

rabbits with normal horse serum (Arthus type)

guinea pigs' with normal horse serum (Arthus type) 
For the purpose of immunization of guinea pigs with horse serum, it was injected subcutaneously twice a week for three weeks, each time in the amount of $0.5 \mathrm{ml}$. The animals were used for the experiment ten days after the last immunization. The results were summarized in Table 4. In guinea pigs, Arthus reaction was very slight, but its reverse type was manifested in a marked way. On the contrary, in rabbits Arthus reaction occurred very strongly against humoral antigen such as horse serum but not so remarkably against cellular antigens such as mononuclear cells of guinea pigs.

Table 4. Arthus and reverse Arthus reactions in rabbits and guinea pigs

\begin{tabular}{|c|c|c|c|c|c|c|}
\hline Exp. & $\underset{\text { immunized }}{\text { Animals }}$ & $\begin{array}{l}\text { Antigen for } \\
\text { immunization }\end{array}$ & $\begin{array}{c}\text { Site of skin reaction, } \\
\text { and its type } \\
\left(\begin{array}{l}\text { Arthus } \ldots \ldots \ldots \text { A } \\
\text { reverse Arthus..rA }\end{array}\right)\end{array}$ & $\begin{array}{c}\text { Intensity } \\
1\end{array}$ & $\begin{array}{l}\text { of } \\
2\end{array}$ & $\begin{array}{l}\text { action } \\
3\end{array}$ \\
\hline 1 & rabbits & 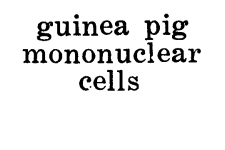 & $\begin{array}{l}\text { guinea pigs, using rabbit } \\
\text { immune serum (rA) } \\
\text { rabbits, using guinea pig } \\
\text { mononuclear cells (A) }\end{array}$ & $\begin{array}{l}\text { W } \\
+\end{array}$ & $\begin{array}{l}\text { W } \\
+\end{array}$ & $\begin{array}{l}\text { 米 } \\
\pm\end{array}$ \\
\hline 2 & rabbits & $\begin{array}{l}\text { normal guinea } \\
\text { pig serum }\end{array}$ & $\begin{array}{l}\text { guinea pigs, using rabbit } \\
\text { immune serum (rA) } \\
\text { rabbits, using guinea pig } \\
\text { normal serum (A) }\end{array}$ & $\begin{array}{l}+ \\
\text { H }\end{array}$ & $\begin{array}{l}\text { H } \\
\text { H }\end{array}$ & $\begin{array}{l}+ \\
H\end{array}$ \\
\hline 3 & \begin{tabular}{|} 
rabbits \\
guinea pigs
\end{tabular} & $\begin{array}{l}\text { normal horse } \\
\text { serum }\end{array}$ & $\begin{array}{l}\text { rabbits, using normal } \\
\text { horse serum (A) } \\
\text { guinea pigs, using normal } \\
\text { horse serum (A) }\end{array}$ & $\begin{array}{l}\text { W } \\
\pm\end{array}$ & $\begin{array}{l}\text { W } \\
\pm\end{array}$ & $\begin{array}{l}\text { H } \\
+\end{array}$ \\
\hline
\end{tabular}

5) Absorption of antibodies from CIS with mononuclear cells: Mononuclear cells obtained from four normal guinea pigs were suspended in $5 \mathrm{ml}$ of saline solution. It was then added to the same amount of CIS and incubated at $37^{\circ} \mathrm{C}$ for 3 hours with occasional shaking. After this treatment, the mixture was centrifuged at 3000 r.p.m. for ten minutes. The cell mass precipitated was washed three times by centrifugation with saline solution and finally resuspended in $5 \mathrm{ml}$ of it. When two guinea pigs each weighing $700 \mathrm{~g}$ and $750 \mathrm{~g}$ were injected intravenously with $1.5 \mathrm{ml}$ of this cell suspension, they died in approximately 5 minutes presenting the typical anaphylactic symptoms. On the other hand, the supernatant (the treated CIS) was examined of its capacity to cause skin reaction in fourteen normal guinea pigs in comparison with two control materials; one was normal rabbit serum and the other was a $1: 2$ dilution of the CIS of pre-treatment. As shown in Table 5, it was found that antibodies responsible for the skin reaction had been almost completely removed from CIS by the absorbing treatment. This was also confirmed by the fact that two guinea 
pigs of $200 \mathrm{~g}$ did not show any anaphylactic symptoms after receiving intravenous injection of $1.5 \mathrm{ml}$ of the supernatant. These observations will tell us that the skin reaction due to CIS were of the nature of cell destruction.

Table 5. Absorption of antibodies from a cytotoxic immune serum with mononuclear cells (examination by skin test)

\begin{tabular}{c|c|c}
\hline \multirow{2}{*}{ Animal No. } & \multicolumn{2}{|c}{ Size of induration in mm } \\
\cline { 2 - 3 } & $\begin{array}{c}\text { right } \\
\text { before treatment }\end{array}$ & $\begin{array}{c}\text { left } \\
\text { after treatment }\end{array}$ \\
\hline 61 & $16 \times 16$ & $10 \times 10$ \\
62 & $10 \times 12$ & 0 \\
63 & $20 \times 20$ & 0 \\
64 & $38 \times 35$ & $13 \times 14$ \\
65 & $28 \times 26$ & 0 \\
66 & $18 \times 18$ & 0 \\
67 & $38 \times 38$ & 0 \\
\hline & after treatment & 0 \\
68 & $5 \times 5$ & 0 \\
69 & 0 & 0 \\
70 & 0 & 0 \\
71 & $11 \times 11$ & 0 \\
72 & $13 \times 13$ & 0 \\
73 & 0 & normal rabbit serum \\
& & 0
\end{tabular}

6) Systemic anaphylactic reaction due to CIS (reverse anaphylaxis): This time, systemic anaphylactic reaction was studied in guinea pigs by injecting CIS intravenously or intraperitoneally for the comparison with tuberculin shock in tuberculous guinea pigs. The intensity of systemic anaphylactic reaction is generally considered to be largely influenced by body weight of animals, amount of antigen and antibody, so the experiments were made of these points at first. Table 6 is the data of the effect of CIS on guinea pigs of various body weight when administered from different routes and in different amounts. Of course, the reactions were severe in the animals of less body weight and in the case of intravenous injection of larger amount of CIS. At this time, however, attentions must be paid to the fact that when CIS was administered intraperitoneally or the injected amount was insufficient the time to death was prolonged and dramatic symptoms were not observed. Table 7 shows systemic tuberculin reactions caused by undiluted OT. When the injections were made intraperitoneally, the reactions occurred in a delayed type similar to the case just described. 
Table 6. Anaphylactic shock caused by a cytotoxic immune serum in guinea pigs of different body weight

\begin{tabular}{|c|c|c|c|c|c|}
\hline \multirow{2}{*}{ Injection route } & \multirow{2}{*}{ Amount injected (ml) } & \multicolumn{4}{|c|}{ Body weight (g) } \\
\hline & & \multicolumn{2}{|c|}{$250-350$} & \multicolumn{2}{|c|}{$670-750$} \\
\hline \multirow{3}{*}{ intraveneously } & 1.0 & 8 minutes & $\bullet$ & O & $\bigcirc$ \\
\hline & 0.75 & in 7 to 15 minutes & $\mathrm{O}$ & $\mathrm{O}$ & $\bigcirc$ \\
\hline & 0.5 & in 6 to 15 hours & 0 & O & $\mathrm{O}$ \\
\hline intraperitoneally & 2.0 & in 8 to 15 hours & & & \\
\hline
\end{tabular}

Table 7. Tuberculin shock caused by OT in tuberculous guinea pigs

\begin{tabular}{lc|cccc}
\hline Injection route & Amount injected & & normal & $\begin{array}{c}\text { Animals } \\
\text { tuberculous }\end{array}$ \\
\hline intraveneously & 0.1 & $\bigcirc$ & $\bigcirc$ & $\bigcirc$ & in a few minutes \\
intraperitoneally & 0.5 & $\bigcirc$ & $\bigcirc$ & $\bigcirc$ & in 18 to 24 hours
\end{tabular}

The animals squatted down in a corner of the cage without eating food and died in that pose. When the injection was made intravenously, the animals died with dramatic shock that is explosive in character. The necropsy of the animals of protracted death showed many similar points between those died of OT and those died of CIS, such as congestion of the peritoneum, swelling of the spleen which was black because of hemorrhage, the bleeding of capillary vessels of the intestine and liver, and the enlargement of the lung. Table 8 was the comparison of the shock test due to CIS or to the anti-red cell serum, which shows that the resulted shock was much intense in the case of the former, although the latter was much higher in the titer of agglutinine. Table 9 showed the reactions due to CIS of various agglutinine titer. Of course, the higher the potency was, the more intensely were elicited the reactions. Through these observations it was suggested that the animals died of the anaphylaxis due to CIS in two different mechanisms; one was acute shock of anaphylaxis itself and another was the indirect result due to the destruction of important organs such as the liver, spleen, bone-marrow caused by the attack of CIS. These organs contain the reteculoendotheliar system in their construction. In this connection, it may be speculated that mononuclear cells are similar to that system in the antigenety and CIS attacks it as a toxin specific to it at least partially. 
Table 8. Anaphylactic shock caused by a cytotoxic immune serum or a hemagglutinine serum in normal guinea pigs

\begin{tabular}{c|c|c|c|c|c}
\hline Serum used & $\begin{array}{c}\text { Agglutinine } \\
\text { titer }\end{array}$ & $\begin{array}{c}\text { Amount used } \\
\text { (in ml) }\end{array}$ & $\begin{array}{c}\text { Body weight } \\
\text { (g) }\end{array}$ & $\begin{array}{c}\text { Live or } \\
\text { death }\end{array}$ & $\begin{array}{c}\text { Time to } \\
\text { death }\end{array}$ \\
\hline & & 1.2 & 230 & 0 & $3.5 \mathrm{~m}$ \\
& & 1.0 & 230 & 0 & $6.2 \mathrm{~m}$ \\
$\begin{array}{c}\text { Cytotoxic } \\
\text { serum }\end{array}$ & \multirow{2}{*}{$1: 800$} & 0.8 & 200 & - & $35.5 \mathrm{~m}$ \\
& & 0.6 & 210 & - & $63.2 \mathrm{~m}$ \\
\hline $\begin{array}{c}\text { Hemagglu- } \\
\text { tinine } \\
\text { serum }\end{array}$ & \multirow{2}{*}{$1: 6400$} & 0.3 & 220 & 0 & \\
& & 1.2 & 230 & 0 & \\
\hline
\end{tabular}

Table 9. Anaphylactic shock caused by a cytotoxic serum of various agglutinine titer in normal guinea pigs

\begin{tabular}{|c|c|c|c|c|c|c|c|c|c|}
\hline \multirow{2}{*}{$\begin{array}{l}\text { Serum } \\
\text { No. }\end{array}$} & \multicolumn{6}{|c|}{ Agglutination } & \multicolumn{3}{|c|}{ Shock } \\
\hline & $1: 100^{*}$ & $1: 200$ & $1: 400$ & $1: 800$ & $1: 1600$ & $1: 3200$ & $0.8 * *$ & 0.4 & 0.2 \\
\hline 1 & H & H & $H$ & H & + & \pm & & & 00 \\
\hline 2 & H & H & $H$ & + & - & - & ? & 000 & 000 \\
\hline 3 & H & H & + & - & - & - & 00 & 000 & \\
\hline
\end{tabular}

7) Protracted death of guinea pigs by the injection of paraffin oil emulsion of CIS: Judging from the preceding experiment, it may be possible that the fatal shock caused by CIS is protracted if it is brought into contact with tissue cells little by little to a sufficient total amount. For this purpose, CIS was used in a form of the water in oil emulsion. The composition was as follows. Paraffin oil 3, Lanoline 2, CIS or normal rabbit serum 4, and Aqua dest. 2. In this proportion they were mixed in a mortar. The mixture was injected subcutaneously to normal guinea pigs in the amount of $2 \mathrm{ml}$. As shown in Table 10, the animals thus treated died in the period of two to seven days after the treatment, but those injected intraveneously with $0.3 \mathrm{ml}$ of CIS alone died almost instantly in a few minutes.

8) Effect of the intravenous injection of CIS upon tuberculin allergy of guinea pigs: As for the procedure to desensitize tuberculin hypersensitivity, two methods have been available; specific desensitization by tuberculin and unspecific desensitization using other agents. Now, on the assumption that tuberculin and CIS may attack the same kind of tissue cells of tuberculous guinea pigs, the effect of CIS on tuberculin hypersensitivity of tuberculous guinea 
Table.10. Delayed fatal shock of guinea pigs due to the injection of paraffin oil emulsion of a cytotoxic immune serum

\begin{tabular}{|c|c|c|c|c|c|c|c|c|c|c|}
\hline \multirow{2}{*}{$\begin{array}{l}\text { Serum } \\
\text { used }\end{array}$} & \multirow{2}{*}{$\begin{array}{l}\text { Mode of } \\
\text { injection }\end{array}$} & \multirow{2}{*}{$\begin{array}{l}\text { Animals } \\
\text { employed }\end{array}$} & \multicolumn{8}{|c|}{ Reaction (fatal shock) } \\
\hline & & & $5 \mathrm{~m} 12 \mathrm{~h}$ & $1 \mathrm{~d} 2 \mathrm{~d}$ & $3 d$ & $4 \mathrm{~d}$ & $5 d$ & $6 d$ & $7 d$ & survived \\
\hline \multirow{2}{*}{$\begin{array}{l}\text { Cytoto- } \\
\text { xic } \\
\text { serum }\end{array}$} & $\begin{array}{c}0.3 \mathrm{ml} \\
\text { in itself, } \\
\text { (intraveneous) }\end{array}$ & 5 & & & & & & & & 0 \\
\hline & $\stackrel{2 \mathrm{ml}}{\underset{\text { in emulsion, }}{\text { (subcutaneous) }}}$ & 12 & & & & & & & 0 & 5 \\
\hline $\begin{array}{l}\text { Normal } \\
\text { serum }\end{array}$ & $\begin{array}{c}2 \mathrm{ml} \\
\text { in emulsion, } \\
\text { (subcutaneous) }\end{array}$ & 5 & & & & & & & & 5 \\
\hline
\end{tabular}

pigs was studied. The experiment was made as follows. Ten guinea pigs weighing $640 \mathrm{~g}$ to $700 \mathrm{~g}$ sensitized three months previously by subcutaneous injection of $30 \mathrm{mg}$ of $\mathrm{BCG}$ were examined of their tuberculin reactivity by the intracutaneous injection of $0.1 \mathrm{ml}$ of a $1: 100$ dilution of OT. The size of the resulted indurations was measured in 24 hours. One week after, half of these animals were injected intravenously with CIS in the amount of 0.25 to $1.0 \mathrm{ml}$, and remaining half were treated in the same way with the same amount of normal rabbit serum. Immediately after this treatment, the animals were examined of their tuberculin allergy in the method described above. Additional two weeks after, the similar experiment was done, but this time tuberculin tests were conducted one day after the treatment with CIS. The results were shown in Table 11, which indicated that the size of tuberculin reaction was evidently decreased in guinea pigs treated with CIS than in those treated with normal serum. The induration itself was, however, very hard, reddish and thick, and the animals kept quite a healthy condition without showing any sign of body weight decrease even after the serum treatment. In an attempt to confirm these findings, a further experiment was undertaken as follows. Four guinea pigs were infected subcutaneously with $0.001 \mathrm{mg}$ of $\mathrm{H} 37 \mathrm{Rv}$ and thereafter the development of tuberculin allergy was pursued. About one month after the infection, when these animals were sensitized to respond to $0.1 \mathrm{ml}$ of a $1: 100$ dilution of OT with the induration of $20 \mathrm{~mm}$ or so, two of them were injected intravenously with $0.2 \mathrm{ml}$ of CIS and remaining two were treated in the same way with the same amount of normal rabbit serum. One day after the treatment, the animals were examined of tuberculin hypersensitivity as usual using a 1:100 dilution of OT. As shown in Table 12, the results showed the same tendency as the previous experiment, but in a more definite way. 
Table 11. Effects of a cytotoxic immune serum upon tuberculin sensitivity of guinea pigs (I)

\begin{tabular}{|c|c|c|c|c|c|c|c|}
\hline \multirow{3}{*}{$\begin{array}{l}\text { Serum } \\
\text { used }\end{array}$} & \multirow{3}{*}{$\underset{\text { No. }}{\text { Animal }}$} & \multirow{3}{*}{$\begin{array}{c}\text { Body } \\
\text { weight }\end{array}$} & \multirow{3}{*}{$\begin{array}{c}\text { Sensitivity } \\
\text { in pre- } \\
\text { treatment }\end{array}$} & \multicolumn{4}{|c|}{ Sensitivity after treatment } \\
\hline & & & & \multicolumn{2}{|c|}{ exp. 1} & \multicolumn{2}{|c|}{ exp. 2} \\
\hline & & & & $\begin{array}{l}\text { serum** } \\
\text { amount } \\
\text { injected }\end{array}$ & reaction & $\begin{array}{l}\text { serum } \\
\text { amount } \\
\text { injected }\end{array}$ & reaction \\
\hline \multirow{5}{*}{$\begin{array}{l}\text { Cytotoxic } \\
\text { serum }\end{array}$} & 371 & 650 & $22 \times 22 *$ & 1.0 & $14 \times 14$ & 1.0 & $13 \times 13$ \\
\hline & 372 & 670 & $27 \times 25$ & 0.5 & $12 \times 12$ & 1.0 & $11 \times 11$ \\
\hline & 373 & 700 & $20 \times 20$ & 0.5 & $15 \times 15$ & 1.0 & $10 \times 13$ \\
\hline & 374 & 690 & $21 \times 22$ & 0.25 & $16 \times 16$ & 1.0 & $9 \times 10$ \\
\hline & 375 & 640 & $20 \times 22$ & 0.25 & $16 \times 16$ & 1.0 & $8 \times 9$ \\
\hline \multirow{5}{*}{$\begin{array}{l}\text { Normal } \\
\text { serum }\end{array}$} & 376 & 650 & $19 \times 23$ & 1.0 & $22 \times 22$ & 1.0 & $22 \times 20$ \\
\hline & 377 & 650 & $20 \times 21$ & 0.5 & $19 \times 20$ & 1.0 & $19 \times 20$ \\
\hline & 378 & 710 & $21 \times 21$ & 0.5 & $20 \times 23$ & 1.0 & $23 \times 22$ \\
\hline & 379 & 680 & $24 \times 26$ & 0.25 & $20 \times 20$ & 1.0 & $20 \times 20$ \\
\hline & 380 & 650 & $18 \times 20$ & 0.25 & $23 \times 21$ & 1.0 & $21 \times 25$ \\
\hline
\end{tabular}

* size of tuberculin reaction in $\mathrm{mm}$

* expressed in $\mathrm{ml}$

Table 12. Effects of a cytotoxic immune serum upon tuberculin sensitivity of guinea pigs (II)

\begin{tabular}{l|c|r|r|r|r|r|c}
\hline $\begin{array}{l}\text { Serum } \\
\text { used }\end{array}$ & $\begin{array}{c}\text { Animal } \\
\text { No. }\end{array}$ & $\begin{array}{c}\text { Body } \\
\text { weight }\end{array}$ & \multicolumn{4}{|c}{ Size of tuberculin reaction in mm } \\
\cline { 4 - 7 } & 1 & 540 & $15 \times 15$ & $20 \times 20$ & $24 \times 24$ & & one day after the treatment \\
\hline $\begin{array}{l}\text { Cytotoxic } \\
\text { serum }\end{array}$ & 2 & 610 & $12 \times 8$ & $13 \times 13$ & $18 \times 18$ & $\begin{array}{c}\text { serum } \\
\text { serument }\end{array}$ & $12 \times 12$ \\
\hline $\begin{array}{l}\text { Normal } \\
\text { serum }\end{array}$ & 3 & 620 & $13 \times 14$ & $18 \times 19$ & $23 \times 20$ & treatment & $21 \times 23$ \\
& 4 & 600 & $12 \times 15$ & $20 \times 20$ & $21 \times 22$ & & $23 \times 27$
\end{tabular}

\section{Discussion}

The underlying principle of the present experiments was, as already stated, based upon two experimental reports that mononuclear cells which exude in response to paraffin oil are the possible carriers of tuberculin antibody and tuberculin reaction may be resulted from the specific cytolysis of these cells by tuberculin. Starting from these somewhat speculative hypothesis, the authors supposed that tuberculin-like reaction may be produced if the cells are destroyed by cytotoxic immune serum instead of tuberculin. The similar or different features of this skin reaction to or from tuberculin reaction have already pointed out. In addition, the difference between the Arthus type and the tuberculin 
type of skin reaction was discussed to form an opinion that the reaction due to CIS is the reverse type of Arthus reaction. On the other hand, however, Benacerraf and Kabat20) showed that Arthus reaction is caused by antigenantibody reaction in the capillary vessels but anaphylaxis is caused by that on tissue cells which retain fixed antibodies. Therefore, in a strict sense of the word, the skin reaction caused by CIS should be called the reverse local anaphylactic reaction rather than reverse Arthus reaction. Tuberculin antibody, if present, has been considered to be a kind of sessile or fixed antibody, although the experimental proof is not yet sufficient. In this connection, tuberculin reaction may be the local anaphylactic reaction. And, according to the view of Takeda ${ }^{16)}$, the skin reaction due to CIS must be the same with tuberculin reaction in its essential nature. One point, however, which is different between these two reactions was the rapidity in which the reactions manifest after the introduction of the antigen or anti-serum. The delayed type of hypersensitivity is in general the expression of bacterial or infectious allergy, and the Arthus type of hypersensitivity was that of the sensitivity caused artificially by the injection of foreign protein. Therefore, in the present state of the informations of the mechanisms of these two types of hypersensitivity, it will be difficult to present any final explanation concerning the rapidity of occurrence of those two reactions. Recently, however, Favour ${ }^{18)}$ offered a very interesting suggestion concerning the mechanism of the delayed manifestation of tuberculin reaction standing upon a series of his investigation on tuberculincytolysis phenomenon. It was as follows in short. When tuberculin is injected intracutaneously to a tuberculous animal, a larger portion of it will adhere to local tissue cells but a small portion will penetrate into the circulation system through which it reachs tuberculous lesions where aggregates of lymphocytes are present. Lymphocytes in that tuberculous focus are then destroyed by tuberculin and release a factor (plasma factor), which can in turn reach the site of tuberculin injection via the plasma and lyse the cells immersed with tuberculin in cooperation with complement. In this way of explanation, it is not always necessary to postulate that every skin cells have tuberculin antibody and the reason why tuberculin reaction occurs in a delayed form is well understood. According to Boyden and Suter ${ }^{21)}$, and Ohara ${ }^{22)}$ and so on ${ }^{23)}$, it has been found that the titer of circulating antibody increases in tuberculous animals after the injection of tuberculin or the desensitization procedure with it. Although there has been no evidence that this antibody is associated with tuberculin allergy, this fact is of particular interest in connection with Francis' theory. On the other hand, there has been a number of evidences to show that cortisone which is concerned with lymphocytes destruction can reduce tuberculin hypersensitivity, and Dougherty24) observed that circulating antibody increased with simultaneous lymphopenia after the administration of ACTH. Aoyama ${ }^{25)}$ discussed the nature of tuberculin reaction from his experimental 
works of nuclemiemia, and $\mathrm{Ono}^{26}$ ) extended this view in association with the function of ACTH. The observation in Exp. 8 may suggest that the pre-treatment of tuberculous guinea pigs with CIS released a factor of Favour and the skin was prepared with it, therefore, the dispersion of tuberculin was inhibited with the result that the area of reaction was small but the induration was very hard in consistence. In other words, the reaction appears to be condensed to a small area.

\section{SUMMARY}

1) A rabbit cytotoxic immune serum (CIS) against mononuclear cells of guinea pigs was prepared by the intravenous injection to rabbits with peritoneal exudate cells of guinea pigs collected with paraffin oil.

2) The skin reaction in guinea pigs due to the intracutaneous injection of CIS was compared with tuberculin reaction. When the appropriate dose of it was used the features of the former reaction were quite similar to those of tuberculin reaction.

3) The only difference was that the reaction by CIS was the immediate type in its manifestation in contrast to the delayed type of tuberculin reaction.

4) By the pre-treatment of with CIS, tuberculin reaction was reduced in its size but somewhat increased in its consistence.

5) The possible mechanism of tuberculin reaction was speculated from the findings obtained.

\section{REFERENCES}

1) Koch, R.: Deutsch Med. Wsschr., 17, 101, 1189, 1891.

2) v. Pirquet, C. E.: Arch. Inst. Med., 7, 259, 383, 1911.

3) Rich, A. R. and Lewis, M. R.: Bull. Johns Hop., 50, 115, 1932.

4) Favour, C. B.: Proc. Soc. Exper. Biol. \& Med., 65, 269, 1947.

5) Heilman, D. H. et al.: Am. Rev. Tuberc., 50, 344, 1944.

6) Heilman, D. H. et al.: Am. Rev. Tuberc., 53, 71, 1946.

7) Aronson, J. D.: J. Immunol., 25, 1, 1933.

8) Nakayama, S. and Abe, E.: Allergy, 2, 94, 1953 (in Japanese).

9) Chase, M. W.: Proc. Soc. Exper. Biol. \& Med., 59, 134, 1945.

10) Kirschheimer, W., and Weisser, R.: Porc. Soc. Exper. Biol. \& Med., 66, 166, 1949.

11) Stavitsky, A. B.: Proc. Soc. Exper. Biol. \& Med., 67, 225, 1948.

12) Nishioka, K.: Jap. J. Exper. Med., 20, 665, 1950.

13) Wesslén, T.: Acta Tuberculosea Scandinavica, 26, 175, 1952.

14) Fukase, S. et al.: The 26th General Meeting of the Japan Bacteriology Association.

15) Wilson, G. S. and Miles, A. A.: Topley and Wilson's Principles of Bacteriology and Immunology, London, Edward Arnold \& Co., 1149 p.

16) Takeda, K.: The 1st General Meeting of the Japan Allergy Association.

17) Amano, J.: Saishin Igaku, 2, 22, 1947 (in Japanese).

18) Favour, C. B.: Advances in Tuberculosis Research, 4, 219, 1951. 
19) Chase, M. W.: Bacterial and Mycotic Infection of Man, J. B. Lippincott Company, Philadelphia, 1948.

20) Benacerraf, B. and Kabat, E. A.: J. Immunol., 64, 1, 1950.

21) Boyden, S. V. and Suter, W. E.: J. Immunol., 68, 577, 1952.

22) Ohara, T.: Allergy, 1, 1, 1952 (in Japanese).

23) Kawakami, Y.: Kekkaku, 29, 163, 1954.

24) Dougherty, T. F. et al.: Science, 98, 367, 1943.

25) Aoyama, K.: The 27th General Meeting of the Japan Tuberculosis Association.

26) Ono, K.: Kaguku, 22, 484, 1952 (in Japanese). 